\title{
Acquiring Water Rights in Mineral Operations in Ghana
}

\author{
By Kweku Ainuson*
}

\section{A. Introduction}

Since independence in 1957 , the mining sector has continued to play an important role in the economic development of Ghana. The mining sector in Ghana is presently the number one foreign exchange earner to the economy ${ }^{1}$. As mineral operations have increased in Ghana, it has put stress on the quantity and quality of water in mining areas ${ }^{2}$. Mining operations are often inextricably linked to water access and use within mining areas. Water use is present throughout the mining value chain. Apart from the fact that mining can take place along river beds and water ways, there are often water diversions before excavations to obtain the mineral laden rocks. Water is used in large quantities for processing of the mineral laden rocks. Water is also used as part of treating mine water waste and mine waste water disposal. However, water has many uses apart from mining and it is not uncommon to see competing interest in water resources use within mining areas. Often, mining operations take place in areas that can be described as ecologically sensitive zones. Thus, the continued growth and success of the mining industry will depend to a large extent on how the competing interests in water resources are managed. Already, news reports are replete with stories of increasing confrontation resulting from the effect of mining activities and the ability of other community members to use water for non-mining purposes. The effect of the mining sector on water pollution has been so severe that it among others things propelled the formation of a media coalition in April 2017 to wage a sustained media campaign against the menace ${ }^{3}$. The media coalition, a coalition of mainstream media houses, media personalities, religious bodies and civil society groups came together to play an advocacy role through the creation of awareness via public education campaigns about the destruction of farmlands and pollutions of rivers and water bodies by illegal mining activities in Ghana. The effect of the mining sector on the water use has not only affected riparian communities, but has severely affected water supply downstream in urban areas where the supply of water is used for both domestic and industrial use. In the Western Region of Ghana, the Ghana Water Company reported in 2017 that the company was losing 5.3 million gallons of water daily due to illegal mining activities on the Pra River. The

* Kweku Ainuson, Senior Lecturer. University of Ghana School of Law.

12018 Budget Statement of the Republic of Ghana. Available at https://www.mofep.gov.gh/budget-st atements/2018 last assessed on 10th March 2019.

2 Akabzaal, T. M. et. al. supra note 2.

3 Media coalition against galamsey launched. Online News Portal article available at http://citifmon line.com/2017/04/05/media-coalition-against-galamsey-launched/ last assessed on $14^{\text {th }}$ February 2018. 
pollution in the Pra River had severely affected water treatment at the Daboase Water Treatment Plant which affects water supply to half of the consumers of the Ghana Water Company in the Western Region of Ghana ${ }^{4}$. In the Eastern Region of Ghana, the turbidity levels were so high in river bodies as a result of mining activities that the Anyinam Water Treatment Plant, Bunso Water Treatment Plant and the Kyebi Water Treatment Plants had to be shut down temporary ${ }^{5}$. These reported cases of pollution have in recent time courted intense negative perception for mining activities in Ghana.

To a large extent, the mining industry can exist and continue to grow if the regulatory regime can strike a fair balance between the mining industry's effect on water use and the ability of the rest of the society to use water. The beginning of the conversation as to striking a fair balance between the competing uses for water is the process of acquiring water rights in mineral operations in Ghana. This paper studies the process of acquiring water rights for mining operations in Ghana. It also considers current approaches to water resource management in mining operations in Ghana. The paper concludes with recommendations as to how to strengthen the regulatory regime to ensure a robust water resources rights acquisition process and how the various regulatory stakeholders can leverage their strengths and capacities to ensure proper alignment in water use in mineral operations in Ghana.

\section{B. Water Resources in Ghana}

Ghana is drained primarily by three main river systems. The Volta River system which is made up of Rivers Oti and Daka, the White and Black Volta Rivers and the Pra, Sene and Afram Rivers constitute the largest river system in the country. The Volta River system covers about seventy percent $(70 \%)$ of the land area in Ghana ${ }^{6}$. Another twenty-two percent $(22 \%)$ of the land area in Ghana is drained by the southwestern river system which is made up of rivers Bia, Tano, Ankobra and Pra. Then the coastal river system which is made up of the rivers Ochi-Nakwa, Ochi, Amissah, Ayensu, Densu and the Tordzie hana covers some eight percent $(8 \%)$ of the land area in Ghana. There are also three separate aquifers which make up most of the groundwater resources in Ghana. First, there is the near coastal aquifer which is unconfined with a depth between $2 \mathrm{~m}$ and $4 \mathrm{~m}$ and contains meteoric water. Then there is the second aquifer which occurs in the Red Continental Deposits of sand clay and

4 Western Region loses $5.3 \mathrm{~m}$ gallons of water daily to galamsey - Water Company. Online News Portal article at http://citifmonline.com/2017/03/22/western-region-loses-5-3-million-gallons-of-wat er-daily-to-galamsey-water-company/ last assessed on $14^{\text {th }}$ February 2018.

5 Bentil, Naa Lamiley. (2018) Water treatment plant at Bunso shut down over activities of illegal miners. News Paper Article in the Daily Graphic Newspaper dated $7^{\text {th }}$ September 2018. Available at https://www.graphic.com.gh/news/general-news/water-treatment-plant-at-bunso-shut-down-over-ac tivities-of-illegal-miners.html last assessed on 10th October 2018.

6 Ainuson, K. (2014) Ensuring Water Supply To Disadvantaged Urban Communities In Ghana: Economics, Law And Policy. Scholars Press. 
gravel. This system is either semi-confined or confined with depths which measure up to $120 \mathrm{~m}$. The groundwater in this aquifer system is fresh and exists in artesian conditions. The third aquifer has an average yield of $184 \mathrm{~m} 3 / \mathrm{hr}^{7}$.

The total renewable water resource per capita in Ghana is estimated to be $56.2 \mathrm{~km} 3 /$ year of which $30.3 \mathrm{~m} 3$ is produced internally and $25.9 \mathrm{~km} 3 /$ year is produced externally. Of the total renewable water, $9.82 \mathrm{~m} 3$ is withdrawn annually for use internally. Internal use is mainly for agricultural purposes which account for $6.52 \mathrm{~km} 3$ of withdrawn water. Municipal and industrial use account for $2.35 \mathrm{~km} 3$ and $0.95 \mathrm{~km} 3$ of withdrawn water, respectively ${ }^{8}$. Within the industrial use sector, mining and the extractive industry are major users. Although the total volume of industrial water use is comparatively small, the impact of water use by the mining and the extractive sector has wide impact for other water users. The use of heavy metals and chemicals as well as unauthorized impoundments and dams in the mining sector have affected the quality and quantity of water used by other water users. The influx of foreign capital mainly from China and the availability of heavy duty equipment on the market have led to a sustained growth in small scale mining activities in Ghana. Due to gabs in the regulatory regime, what is meant to be small scale mining has metamorphosed into indiscriminate and unlawful mining activities in the towns, forests and river bodies of mining activities. These operations cannot be described as small scale mining operations because of machinery used and the size of the areas mined. Mining activities have therefore led to increased pollution levels in some of the major water bodies in Ghana.

\section{Water Resource Management in Ghana}

The management of water resources in Ghana is through the Water Resources Commission. The Water Resources Commission was set up by the Water Resources Commission Act, 1996 (Act 522) to regulate and manage the utilization of water resources in Ghana and other matters incidental thereto ${ }^{9}$. In Ghana, there are two main sources of water law, namely customary law and statutory law. Under customary law, water was seen as a community property and therefore could not be owned by any individual. Prior to the advent of colonialism in Ghana, there were elaborate traditional systems, regimes and rules formulated by various ethnic groups and localities for the use of water resources. Colonialism and the creation of the modern Ghana set in motion the processes that eventually led to the creation of statutory interventions to regulate water use among different users. In the face of increasing pressure on water use resulting from dwindling supply and increasing population, the government of the modern Ghana has introduced various pieces of legislation

7 Ibid page 83 .

8 Food and Agriculture Organization of the United Nations. Country Fact Sheet: Ghana, 2005. Aquastat: Global Water Information System. Available at http://www.fao.org/nr/water/aquastat/data /cf/readPdf.html?f=GHA-CF_eng.pdf (last accessed on 6/11/2016).

91992 Constitution of Ghana, Article 269. 
and policies to affect water use management. The customary management of water has therefore changed in the face of modern challenges facing the water sector.

Under customary law, water in its natural state such as rivers, lakes, ponds and streams were regarded as a communal property which could not be owned by an individual. Water bodies existing in communities were seen as the property of the community and held in trust by the traditional authorities for the benefit of the community. In the rainy season when water was in abundance, all members of the community as well as outsiders had unfettered access to draw water for their individual use. In the dry season however, members of the community had priority of use over nonmembers of the community. Outsiders had limited access to draw water on the basis of availability and sometimes based on alliance with the water owning community. It is important to note that under customary law, no matter how long a member of the community used water from the communal water source, such use did not ripen to ownership or a right to the amount of historical use. The traditional authorities had the right to make reasonable apportionment of water to all members of the community based on need during dry season. Whether it was the dry season or wet season, the traditional authorities had elaborate taboos which were shrouded in mysticism for the management of quality and quantity of water. For instance, it was forbidden for women who were in their menstrual cycle to go to the river side ${ }^{10}$. In addition, it was forbidden for farming or animal husbandry to be done close to the community water. Fishing from water bodies were prohibited during a certain time of the year and the closed season then allowed the fishes time to spawn to allow sustainable fishing. These taboos were designed to regulate the use of water resources to ensure quality and sustainable quantity ${ }^{11}$. Enforcement of taboos was based on the common belief systems of the community folks that a higher being will punish them if they fell short of the rules ${ }^{12}$. In addition, for the fear that individual sins may have communal repercussions, neighbors as well as people who witnessed a breach, reported rule breakers to the authorities for punishment. However, as communities grew and became more cosmopolitan the traditional rules and belief systems began to break down. In addition, growth of the modern State system meant that the State became increasingly seen as the repository of power and the entity responsible for shaping public life and public policy as opposed to the traditional authorities. The position of the State to make policy became more desirable as the State was seen as the entity likely to view issues of water management from a holistic view as opposed to the traditional models that were mainly based on local conditions.

10 A taboo is defined as a social or religious custom prohibiting or restricting a particular practice or forbidding association with a particular person, place, or thing. Merriam Webster English Disctionary.

11 Appiah-Opoku, S. (2007) Indigenous Beliefs and Environmental Stewardship: A Rural Ghana Experience. Journal of Cultural Geography, Volume 24, 79-98; Dyasi, H.M. (1985) Culture and the Environment in Ghana. Environmental Management 9: 97.

12 Ibid, Dyasi, H.M. supra. 
The customary law rules pertaining to water use have been supplanted with statutory law that has significantly affected ownership and use of water resources. At present, the ownership, use and management of water resources is governed by the Water Resources Commission Act of 1996, Act 522. Under section 12 of the Water Resources Commission Act, "The property in and control of all water resources is vested in the President on behalf of, and in trust for the people of Ghana". Thus, no entity can divert, dam or in any way use water in its natural state for mining without reference to the Water Resources Commis$\operatorname{sion}^{13}$. The Water Law created an apex regulatory body known as the Water Resources Commission and clothed it with certain specific functions with respect to use and rights in water. Notable among these functions are;

a. Regulation and management of the utilization of water resources as well as the coordination of appropriate policies related thereto.

b. Make comprehensive proposals for the utilization, conservation, development and improvement of water resources.

c. Grant water rights to different water users

d. Disseminate important data on water resources in Ghana

e. Monitor and evaluate programs for the maintenance of water resources

f. Advise government and pollution control agencies in Ghana on matters concerning the management and control of water resources.

However, these statutory changes to ownership and use of water resources took place without the knowledge of the customary custodians of water resources ${ }^{14}$. Thus, in many areas outside the big cities, it is the traditional rules on water use that continue to exist in practice. The traditional authorities still retain a lot of power with respect to water use and management. Water users such as miners and farmers in the small and rural areas therefore seek their permission for the use of water resources from the traditional authorities in their area of operations.

\section{Mining in Ghana}

The mining industry is one of the oldest industries in Ghana dating to the $1500 \mathrm{~s}$ with gold being the predominantly mined mineral. The industry has continued to be one of the important backbones of the economy of Ghana generating high employment figures and supporting local industries. Although the discovery and production of oil is contributing hugely to the GDP, the mining industry still remains the single largest contributor to GDP

13 Water Resources Commission Act, 1996 (Act 522) section 13.

14 Sarpong G. A. (2004), "Going Down the Drain? Customary Water Law and Legislative Onslaught in Ghana," pp.13. Paper commissioned by FAO as part of its studies on effect of legislation on Customary Water Rights.

FAO Legal Papers on Line at http://www.fao.org/legal/pub-e.htm. 
in Ghana. ${ }^{15}$ There are many towns in Ghana whose existence and growth are inextricably linked to the mining industry in the community. In these mining towns, mining activities are a combination of large scale mining which is dominated by big foreign corporations and small scale mining which is dominated by individuals and small local mining companies. There is also a growing small scale mining industry which is as old as the mining industry itself and largely unregulated. It is locally called 'galamsey' or referred to by policy makers as illegal small scale mining.

At present, Ghana is the second largest producer of gold in Africa and third largest in manganese and aluminum. There are also major productions of diamonds, bauxite and clinka ${ }^{16}$. In spite of the long history of mining in Ghana, there are still lucrative prospective areas in Ghana and investment capital continue to flow into the mining sector. The mining sector has been listed as one of the priority sector for investment by the Ghana Investment Promotion Center ${ }^{17}$. The prospective areas lie within the vast water systems within Ghana.

\section{E. Types of Mining Activities}

Mining operations in Ghana can be classified into two broad categories in accordance with the scale of operations as well as the characteristics of the operators. The two broad categorizations are large scale mining operations and small scale mining operations. Definitions for small scale or artisanal mining are often disputed ${ }^{18}$. However, in general, small scale mining operations often exploit small deposits, have little capital, are labour intensive, struggles to access market and support services. They often have low health and safety standards and have significant negative externalities on the environment. On the other hand, large scale mining is associated with large companies that are likely to be multinational in nature. They are more organized with sophisticated business models and are often able to tap large capital from capital markets. They are more likely to engage in concession mining covering hundreds of square kilometers.

Small scale mining activities have their antecedent in the very history of mining activities in Ghana. Until the advent of concession mining with the coming of European colonization, mining activities were artisanal, meant more for survival and subsistence as opposed to an organized business. However, despite its humble beginnings, small scale mining still remains important and in terms of actual number of people involved in it far out-

15 The Ghana Chamber of Mines Performance of the Mining Industry in GHANA - 2018. A publication by the Ghana Chamber of Mines. June 2019.

16 KPMG Global Mining Institute: Ghana Country Mining Guide. 2014. Available http://www.kpmg. $\mathrm{com} / \mathrm{GH} / \mathrm{en} /$ Documents/ghana-mining-guide\%202014.pdf last assessed on 17/1/2016.

17 Ghana Investment Promotion Center's Investment Sectors in Ghana. Available at http://www.gipc ghana.com/invest-in-ghana/sectors.html last assessed on 17/1/2016.

18 Buxton, A. (2013). Responding to the challenge of artisanal and small-scale mining. How can knowledge networks help? IIED, London. Available at http://pubs.iied.org/16532IIED.html last accessed on 23/1/2016. 
strips large scale mining activities. It is estimated that there are about one million people directly involved in small scale mining as opposed to an estimated twenty-eight thousand in the large scale mining operations ${ }^{19}$. The number of people directly involved in small scale mining has increased over the years as has its contribution to the overall mineral production numbers in Ghana. In 1989, the contribution of gold production from the small scale mining industry to total production in Ghana was $2 \%$. This grew steadily to $28 \%$ of total production in 2011 and reached a high of $34 \%$ of total production of gold in 2012 .

Until 1989, small scale mining existed in the fringes, was unregulated and largely viewed as illegal. Successive governments after independence focused on the colonial government's policy of promoting the interest of large scale mining because of the potential foreign direct investment that is associated with the large scale mining as well as the direct revenue it brought to the government. Although in 1989, the Small Scale Gold Mining $\mathrm{Act}^{20}$ was passed to regulate the activities of the small scale mining operations in Ghana, their activities have still remained on the fringes with the regulatory authorities struggling to properly regulate their activities. Historical practice of operating outside the ambit of the law, together with a combination of cumbersome registration process and lack of presence of the regulatory authorities at mining areas have largely contributed to the many small scale operators operating illegally. Although there are some small scale miners who are properly registered and operate within the confines of the law, it is difficult to tell them apart as majority of small scale miners operate without any form of formal registration and regulation.

Large scale mining is more likely to be legal and is often associated with international mining companies. The companies that engage in large scale mining are more likely to be multinational companies, are more organized, well-coordinated in their activities and operate over large concessions with heavy machinery and equipment. Because they are well organized and can be easily identified, they are often the focus of regulatory interventions and their contribution to the economy can be easily calculated and quantified.

The process of large scale mining usually involves prospecting, production and processing of minerals before they are exported. In these processes, water plays an important role. Apart from using water to cool their machinery such as cutting edges and also for reducing friction induced burst of flames, water is also used as part of the method of separating minerals from the mineral laden rocks and dirt. Water is often drawn from groundwater aquifers or transported from nearby water bodies for use. As part of their environmental obligations, waste water is expected to be treated before being discharged into the environment. However due to the often high cost of waste water treatment and a general lack of regulatory enforcement, it is not uncommon for waste water to be discharged or spilled directly into the environment. For instance, in 2009 there was a cyanide spillage at the

19 McQuilken, J and Hilson, G (2016) Artisanal and small-scale gold mining in Ghana. Evidence to inform an 'action dialogue'. IIED, London.

20 Small Scale Gold Mining Act, 1989 (PNDCL 218). 
Ahafo Mine of Newmont Ghana Gold Limited. The spillage reportedly contaminated water bodies around the mine area and the source of water for about six communities in the area. According to WACAM, a civil society group operating in the area, although the incident was reported immediately it occurred, it took the Environmental Protection Agency some four days to visit the area. In its statement after the event, WACAM indicated that the inability of the Environmental Protection Agency officials to visit the site timeously meant that water samples taken would not give an accurate indication as to the extent of the cyanide spillage ${ }^{21}$.

Also, in June 2006, there was a reported cyanide spillage at the mine site of Bogoso Gold Limited when the tailings dam was breached. The cyanide-laden tailings poured into the external environment and polluted the Ajoo stream and other water bodies which served as the main drinking water for communities in the area. About thirty community members who drank water or ate sea food from the water bodies reported a number of health conditions ranging from dizziness, headaches, stomach aches, loss of appetite, itching tongue and skin itches ${ }^{22}$.

Although the environmental permitting process in the mining industry presents a comprehensive approach to dealing with the effect of mining activities on water resources, it has for the most part failed woefully to check the misuse of water resources. Mining companies are expected to obtain an environmental permit prior to undertaking mineral operations. Before an environmental permit is issued, a mining company must among other things indicate its water use and the measures it has put in place to minimize to an acceptable level the operations of its activities on water resources. These measures serve as part of the guiding principles by which the regulatory agencies monitor the activities of the mining company. However, a combination of policy gaps, low capacity and weak enforcement of regulatory agencies have led to weak controls of the impact of mining companies on water resources in Ghana ${ }^{23}$.

Small scale mining has always been attributed with the use of simple implements by local people to mine for subsistence. Unlike the large scale mining which is often foreign owned and employs locals to fill low level positions, small scale mining employs large number of locals and contributes significantly to the wellbeing of the people in the mining areas. It is estimated that the small scale mining industry alone supports the livelihood of approximately 4.5 million people. ${ }^{24}$ Thus, in 1989 when the Small Scale Mining Law was

21 Newmont Down playing Extent of Cyanide Spillage-WACAM, 17 $7^{\text {th }}$ October, 2009. Modern Ghana Online News Articles. Available at https:/www.modernghana.com/news/244322/1/newmont-dow nplaying-extent-of-cyanide-spillage-wac.html last assessed on 8/11/2016.

22 Cyanide Incidences - Spills and Leaks. The Rainforest Information Center. Available at http://ww w.rainforestinfo.org.au/gold/spills.htm last assessed on 8/11/2016.

23 McQuilken, J and Hilson, G (2016) Artisanal and small-scale gold mining in Ghana. Evidence to inform an 'action dialogue'. IIED, London.

24 McQuilken, J and Hilson, G (2016) Artisanal and small-scale gold mining in Ghana. Evidence to inform an 'action dialogue'. IIED, London. 
passed, it was seen as, among other things, an avenue to ensure equity and bring the fringe economy into the mainstream.

Policy makers thought that because small scale mining was generally artisanal in nature, regulatory framework should be simplified to make it easy for miners to comply. In addition, since the aim of the new policy on small scale mining was partly to remove it from the fringes of the law and bring it under regulatory authority, it was necessary to avoid a cumbersome process that deterred miners from operating under the ambit of the law. Thus, although small scale mining operators have to obtain an EPA permit before commencing mineral operations, they are not, in general, required to use the environmental impact assessment formula to obtain environmental permits. The permitting process is therefore largely administrative and involves an administrative decision made at the office of a bureaucrat over a submitted form without necessarily embarking on a field visit to ascertain the veracity of submitted environmental plans. ${ }^{25}$ Once the processing fee is paid, an officer at the Environmental Protection Agency reviews the application process without necessarily a trip to the site to ascertain materials contained in the application. This simple process is often not enough to ensure adherence to environmental regulations by a subsistence small scale miner. This regulatory process is coming at the back of the heels of a poorly resourced Environmental Protection Agency which makes it difficult for the personnel of the Agency to conduct regular compliance inspection of mine sites. However, despite the fact that this permitting process is meant for small scale miners, in practice the activities of the small scale miners are anything but small. In fact, here the policy thinking has fallen miles behind the actual practice. The small scale miners of today do not use simple implements and they are in the mining industry not for subsistence but are astute business tycoons ${ }^{26}$.

Although small scale mining is by law reserved for Ghanaian citizens ${ }^{27}$, many Ghanaian citizens have found 'silent' partners in China, Eastern Europe and Russia to expand their business. ${ }^{28}$ The influx of foreigners has now given small scale miners ready access to heavy duty equipment like excavators and bull dozers. With the typical small scale concession being about twenty-five acres, operators can do a lot of damage with the heavy equipment. To show the dexterity of some small scale miners, they have registered different business entities with different names and have applied for and been given concessions that are contiguous to each other. Thus, there are some small scale miners holding four mining

25 Environmental Inspectors are supposed to be present at all the District Mining Offices. Inspectors are expected to inspect mining operations in line with the submitted environmental plans as well as best practices in mining.

26 K.J.Bansaha, K.J., Yalley, A.B., Dumakor-Dupey, N. (2016) The hazardous nature of small scale underground mining in Ghana. Journal of Sustainable Mining Volume 15, Issue 1.

27 Minerals and Mining Act, 2006 (Act 703) section 83.

28 Hilson, G., Hilson, A., Adu-Darko, E. (2014) Chinese participation in Ghana's informal gold mining economy: Drivers, implications and clarifications. Journal of Rural Studies Volume 34. 
concessions of twenty-five acres each with a combined concession area of one hundred acres.

Apart from the small scale miners who were captured under the ambit of the small scale mining law $^{29}$, there are hordes of other small scale miners who have no form of registration and operate entirely outside the regulatory control. They are usually referred to as galamsey operators. Their operations are illegal as they have no form of registration and are therefore unknown to the regulatory authorities. Their operations are the same as the legal small scale operators, the only difference being that they do not have a permit to operate. In recent times, there are Chinese and Russian citizens who have boldly entered into galamsey operations in mining areas in Ghana ${ }^{30}$.

With very little regulatory oversight, the activities of small scale miners have been very destructive to the environment. Many water bodies in the mining communities are now laced with heavy chemicals and are discolored due to mining activities. For instance, the Ghana Water Company has complained variously that the pollution of water bodies by small scale operators is making it cost prohibitive for them to treat water for urban and industrial use. River banks and natural dams have been destroyed through the activities of small scale miners resulting in severe flooding in the catchment area of some of the major rivers in mining communities with serious consequences. For instance, in 2011 the Birim River in the Eastern Region broke it banks during the raining season and killed 5 people ${ }^{31}$.

Environmental concerns, especially the pollution of water bodies by mineral operations have been rife in Ghana. In 2007, the Commission on Human Rights and Administrative Justice (CHRAJ) in Ghana in a study on the impact of mining reported that many rivers and streams which served as a source of water supply for communities have been heavily polluted.

It is important to note that water pollution associated with mining is not limited to small scale miners and galamsey operators, operations of large mining companies have also contributed to water pollution in Ghana. As earlier indicated, since 2001, there have been numerous reports of cyanide spillage from major mining companies into water bodies in their concession areas with serious environmental consequences. The negative impacts of the mining industry on water would have to be taken seriously by the authorities if Ghana hopes to continue its dependence on the mining industry. The problem is exacerbated by the fact that the Water Resources Commission and other regulatory bodies have little footprints in mining areas. Traditional leaders continue to wield authority in the grant of right to mining sites and use of water for mining purposes although they have no such right in law. There seems to be a global concern that environmental issues would continue to

29 The small mining was first legalized under the Small Scale Mining Law, 1989 (PNDCL 218). At present, small scale mining is regulated under the Minerals and Mining Act, 2006 (Act 703).

30 Supra note 42.

31 President Atta Mills and the Eastern Region Minister visited communities affected by the flooding which was attributed to illegal mining in the area, $25^{\text {th }}$ July, 2011. http://news.peacefmonline.com/ pages/news/201107/58805.php?storyid=100\& last assessed on 13/2/2016. 
adversely affect the ability of countries to engage in mining operations. Although favorable economics and improved technology will make it possible to find new mineral deposits and extract them, it is environmental cost which will play a deciding role as to the viability or otherwise of mineral operations ${ }^{32}$.

\section{F. Mining Resources Management}

Minerals in their natural state belong to the people of Ghana collectively ${ }^{33}$. The President of Ghana holds minerals in trust for the people of Ghana and subject to the provisions of the 1992 Constitution of Ghana ${ }^{34}$. Land ownership is therefore divorced from the ownership of mineral resources. The right of the owner or lawful occupier of land does not therefore extend to the minerals that are found in or on or beneath the land. Per the provisions of the 1992 Constitution of Ghana, the President acting through Parliament and other institutions of State therefore makes decisions affecting the disposition of minerals in Ghana.

The Minerals Commission is a government agency established under the 1992 Constitution of Ghana to serve as the apex regulatory body for mining activities in Ghana ${ }^{35}$. The Minerals Commission is primarily responsible for the formulation of policy for the exploitation of minerals for the benefit of the State as well as monitoring the implementation of government policies within the sector ${ }^{36}$. The Minerals Commission also has responsibilities for ensuring environmental regulations in the mining sector to ensure that mining activities are carried out in a modern, safe and environmentally sound manner ${ }^{37}$. In fact, under section 18(2) of the Minerals and Mining Act, holders of mineral rights are enjoined to comply with all applicable regulations made under the authority of the Act for the protection of the environment as they relate to the exploitation of minerals. To this, the Minerals Commission has formulated Ghana's Mining and Environmental Guidelines ${ }^{38}$ for use by mining companies. Although the Environmental Protection Agency has the lead obligation to ensure environmental protection, the obligations of the Minerals Commission to ensure that mining companies comply with their environmental obligations including water use and disposal have been clearly established. This matter was settled in the leading case of Center for Public Interest Law and another vrs. Environmental Protection Agency and

32 Mudd, G.M., Sustainability and Mine Waste Management-A Snapshot of Mining Waste Issues. Waste Management \& Infrastructure Conference - IIR Conference, Melbourne, September 2007.

331992 Constitution of Ghana, Article 257(6).

34 Ibid.

35 Ibid Article 269.

36 Minerals Commission Act, 1993 (Act 450), Section 2.

37 Ibid, see also Minerals and Mining Policy of Ghana, Unpublished Policy Statement by The Minerals Commission of Ghana, November 2014.

38 "These guidelines were designed by the Minerals Commission and they formed the basis for Environmental Regulations under the Minerals and Mining Law (PNDCL 153) 1986. 
2 Others (Bonte Mines Case) ${ }^{39}$. In this case, the Plaintiffs had sued the $1^{\text {st }}$ Defendant Environmental Protection Agency and $2^{\text {nd }}$ Defendant Minerals Commission to compel them to perform their statutory obligations in respect of damages caused to the environment by the $3^{\text {rd }}$ Defendant mining company. The Minerals Commission among other things argued before the court that it had no responsibility for the coordination of environmental policies in respect of exploration of mineral resources. It stated further that environmental policies in the mining sector were the preserve of the Environmental Protection Agency and that the function of the Minerals Commission is to grant mineral licenses on the basis of the environmental permits granted by the Environmental Protection Agency ${ }^{40}$. In the opinion of the Minerals Commission, the obligation to ensure the compliance of the conditions in the Environmental Permit is that of the Environmental Protection Agency ${ }^{41}$. The High Court held that the Minerals Commission's duties went beyond just issuing mining permits and that inherent in its duty is a statutory obligation to monitor and ensure that mining companies do not breach their environmental obligations ${ }^{42}$.

Under the Minerals and Mining $\operatorname{Law}^{43}$ a person ${ }^{44}$ cannot undertake mineral operations unless the person has been granted a mineral right under a mineral license ${ }^{45}$. Because the ownership of minerals are divorced from ownership of land, the holder or owner of land is also required to obtain a mineral right before undertaking mineral operations on the land that he holds. The mineral rights that are generally granted by law are reconnaissance rights, prospecting rights and production rights. These rights come with different duties and obligations that are spelt out in law. In general, the acquisition of one right does not automatically entitle the holder to the acquisition of the other rights.

Small scale mining is described as a different and separate category of mining activity in the Minerals and Mining Act. Small scale or artisanal mining operations are reserved specifically for Ghanaian citizens or legal vehicles for doing business owned by Ghanaian citizens ${ }^{46}$. Small scale mining rights are often granted over land of about twenty-five acres or less and its patrons are expected to use artisanal tools and simple implements in the exploration and production of minerals.

39 Center for Public Interest Law and Center for Environmental Law vrs. Environmental Protection Agency, Minerals Commission and Bonte Gold Mines. Suit No. A(EN) 1/2005. Fast Track High Court Accra, $27^{\text {th }}$ March, 2009 Before Iris May Brown (JA) Sitting as an Additional High Court Judge. (Unreported).

40 Ibid at page 3.

41 Ibid.

42 Ibid at page 10.

43 The Minerals and Mining Act, 2006 (Act 703).

44 A person is defined under section 10 of the Minerals and Mining Act, 2006 (Act 703) as a body incorporated under the Companies Code 1963 (Act 179) or under the Incorporated Private Partnerships Act 1962 (Act 152) or under an enactment in force.

45 The Minerals and Mining Act, 2006 (Act 703) section 9.

46 Ibid at section 83 . 
The government Minister in charge of minerals receives and grants applications for mineral rights in Ghana. The Minister acts on the advice of the Minerals Commission in granting minerals rights. In practice, since the Minerals Commission is the regulatory body with the technical know-how, applications for mineral rights addressed to the Minister are submitted through the Minerals Commission. The Commission then processes and assesses the application before making a recommendation to the Minister to grant or not to.

Prior to undertaking mineral operations, the holder of mineral rights is also required to obtain permission from the Forestry Commission ${ }^{47}$ as well as obtain an environmental permit from the Environmental Protection Agency. Where the proposed mineral operations is likely to use water in its natural state and/or affect water resources, the holder must also obtain a water right/use permit from the Water Resources Commission.

\section{G. Acquiring Water Rights in Mining Operations}

The Water Resources Commission governs the allocation of water resources generally ${ }^{48}$. However, the process of acquiring water rights for mining activities is governed by the Water Use Regulations, 2001 (L.I. 1692) and Drilling License and Groundwater Development Regulations 2006 (L.I. 1827). These regulations were promulgated pursuant to section $35^{49}$ of the Water Resources Commission Act. The Water Use Regulations details the specific administrative procedures a mineral rights holder must go through to obtain a water permit for purposes of exercising mineral rights.

The Minerals and Mining Law ${ }^{50}$ provides that the holder of a mineral right must obtain the requisite approvals or licenses from the Water Resources Commission before it may “... obtain, divert, impound, convey and use water from a river, stream, underground reservoir or watercourse within the land the subject of the mineral right" 51 .

Although the Water Resources Commission has the legislative right to grant licenses to mineral rights holders for the use of water resources, the management of water use in mineral operations is based on an integrative approach which imposes an obligation on a number of government agencies. The long title of the Water Resources Commission Act describes the Act as "An Act to establish a Water Resources Commission, to provide for its composition and functions on the regulation and management of the utilisation of water resources in Ghana and for related matters" ${ }^{52}$. It is clear that the Water Resources Commission is the lead government agency responsible for the management of water resources among mineral rights holders. However, equally responsible for water resource

47 A permit/license from the Forestry Commission is required if the mining operation will take place in a forested area. See Forest Commission Act 1999 (Act 571) section 2.

48 Water Resources Commission Act, 1996 (Act 522).

49 Ibid at section 39.

50 Minerals and Mining Act, 2006 (Act 703) section 17.

51 Ibid section 17.

52 Ibid, see the Long Title. 
management among mineral rights holders are the Minerals Commission and the Environmental Protection Agency. The Minerals Commission has a function to regulate and manage the utilization of mineral resources in Ghana and co-ordinate the policies in relation to them ${ }^{53}$. As part of its function of coordinating policies in relation to mineral resources, the Minerals Commission is also mandated to advice the Minister responsible for mining on the regulation of mineral resources. In addition, the Environmental Protection Agency has the function of regulating the environment, in this context, through issuing environmental permits to mineral rights holders and also monitoring those permits to ensure that holder operate within the terms and conditions of the said permits. In fact, it can be clearly gleaned from the above that there seem to be overlapping functions of these government agencies with respect to the management of water use among mineral rights holders. This observation was made by her Ladyship Iris May Brown (JA) in the Bonte Mines case. After reviewing the functions of the Environmental Protection Agency and the Minerals Commission with respect to environmental protection, the court stated that "it is true that its [Minerals Commission] functions and obligations overlap with those of the various bodies including the [Environmental Protection] Agency other officials of the Ministry of Mines under the Minerals and Mining Act" ${ }^{\prime 5}$. In fact, such overlapping functions may spell doom for the management of water resources among mineral rights holders as agencies may be prone to turf wars or work at cross purpose. It is not uncommon for government agencies to engage in unhealthy competition when their functions are not clearly spelt out or seem to overlap. ${ }^{55}$ Thus, in situations where no one institution is given a clear monopoly or a carefully defined role as to water use management in mineral operations, it may be difficult for the various agencies to work together for the benefit of the people of the State. It may also lead to a situation where it becomes difficult to apportion blame and hold agencies responsible for lapses in regulatory authority.

It seems that Parliament intended for these agencies to work together to manage water use in mining operations. In fact, collaboration among government agencies has been touted as desirable and necessary to increase public value ${ }^{56}$. It is mutually beneficial for the agencies involved as it helps them to focus their commitment to a set of goals or

53 The Minerals Commission Act, 1993 (Act 450) section 2.

54 Supra note 32 at page 10.

55 Macey, Jonathan. R. Administrative Agency Obsolescence and Interest Group Formation: A Case Study of the Sec at Sixty. 15 Cardozo L. Rev. 909 (1993 - 1994); Robbins, Harvey (1989) Turf Wars: Moving from Competition to Collaboration. Scott Foresman Trade; Graham Haughton, Jamie Peck \& Ian Strange (1997) Turf wars: The battle for control over English local economic development, Local Government Studies, 23:1, 88-106,; see also Turf war between University of Ghana and the Ministry of Health over new Medical Center. Online News Article dated $16^{\text {th }}$ January 2018. Available at http://ghananewsonline.com.gh/turf-war-between-university-of-gha na-and-the-ministry-of-health-over-new-medical-center/?pr=56294\&lang=ar. Last assessed on 16/8/2018.

56 Bardach, E. (1998) Getting Agencies to Work Together: The Practice and Theory of Managerial Craftsmanship,Brookings Institution Press, Washington, DC. 
jointly developed structures that allows for shares responsibility ${ }^{57}$. When the collaborative relationship of the agencies is based on trust and a shared vision to solve a public problem, it enhances the ability of the agencies to achieve better outcomes. In management of water resources and mineral resources, the Water Resources Commission and the Minerals Commission may see their respective problems differently. However, collaboration will allow the agencies to explore their differences and collectively search for constructive and mutually beneficial solutions that may otherwise be impossible to achieve. They may be able to achieve growth in the mining sector as well as a sustainable use of water resources from a comprehensive analysis of the challenges and opportunities that they are faced with.

The enabling legislation are designed to ensure that the Water Resources Commission works with other agencies in the discharge of its obligations. Thus, the governing body of the Water Resources Commission includes representatives from the Environmental Protection Agency and the Minerals Commission ${ }^{58}$. This phenomenon does not seem isolated within the public sector in Ghana. A typical example can be found in the 1992 Constitution of Ghana where under article 86, the composition of the governing board of the National Development Planning Commission is made up of representatives from different agencies and sectors. Here, the constitution recognizes that development is a shared responsibility. Although the individual agencies may have their own conception of what advances their respective agencies, collaboration ensures better outcomes for the national development of Ghana. The constitution in this regard views national development as a shared problem. Dealing with the problem therefore calls for collaboration through series of interrelated activities by the agencies to address the shared problem and achieve common goals. Examples of such collaboration in Ghana can be found in wide ranging sectors such as data protection, petroleum and telecommunication.

Collaboration in the mining and water resources sector is therefore not a new phenomenon, but part of a new ethos to drive agency integration with the view to enhance overall efficiency and effectiveness. In this direction, it was observed by the Court in the Bonte Mines case, the Minerals Commission sits on various committees with the Environmental Protection Agency to look at environmental impacts statements of mining companies before environmental permits are issued. In fact, within the Minerals Commission there is a standing technical committee that is constituted to consider applications for mineral rights before the Minerals Commission makes a recommendation to the Minister in charge of minerals to issue a license for the exercise of mineral rights. The Minerals Commission recognizes that the exercise of mineral rights affects many other resources and therefore adopts an integrative approach to consider mineral applications. Mining operations may take place in forests, over land and may take place near a water body or affect a water body. It may also require lots of water for purposes of processing the mineral from

57 Mattessich, P., M. Murray-Close and B. Monsey(2001) Collaboration: What Makes It Work,Amherst H. Wilder Foundation, St Paul, Minnesota.

58 The Water Resources Commission Act, 1996 (Act 522) section 3. 
the mineral laden ore. The standing committee in recognition of the symbiotic nature of mineral exploitation has as part of its members a representative from the Water Resources Commission, Forestry Commission, Lands Commission, Geological Services Department and the Environmental Protection Agency. Therefore, when an application is submitted to the Minerals Commission for processing, the Minerals Commission will take the views of the representatives of the other agencies with respect to the technical competency of the application as it affects their respective agency's scope of work. In this direction, the representative of the Water Resources Commission is able to advice the committee as to the effect of the proposed mineral operations on water bodies in and around the mining area. If the proposed mining operation will adversely affect water resources for which there can be no appreciable remedial action to reduce or minimize the adverse effect, the Minerals Commission may advice the Minister to exercise his/her power under section 4 of the Minerals and Mining Act to set the land aside from mining for being an ecological fragile area. In the same vein, if by the nature of the application the applicant must obtain a water use license the Water Resources Commission can indicate such requirement so that the grant of the mineral right by the Minister will be subject to a water use license obtained from the Water Resources Commission.

The integrative approach ensures that relevant agencies are able to combine their resources and expertise to make sure that problems are tackled holistically as opposed to a piecemeal approach ${ }^{59}$. It also ensures judicious use of resources especially in a developing country like Ghana where resources are limited. This approach allows agencies to be present in areas of the country where they are not necessarily present physically. For instance, although the Water Resources Commission is not present throughout the Mining Districts of Ghana, by collaborating with the Environmental Protect Agency and the Minerals Commission, it is able perform its functions in the Districts that it is not physically present. The Water Resources Commission has also collaborated effectively with the police service to monitor and prosecute water use offences. For instance between 2012 and 2014, the Water Resources Commission embarked on the training of police personnel to assist it enforce water use offences under the Water Resources Commission Act ${ }^{60}$.

In spite of being set up to work together, these agencies which directly affect mineral rights and water resources use are clothed with enough power on their own to regulate the use of water resources among mineral rights holders. Under section 12 of the Environmental Protection Agency Act, the Environmental Protection Agency (EPA) may by notice in writing require any mining operations which in the opinion of EPA has or is likely to have adverse effect on the environment to submit to the EPA an environmental impact

59 Sussman, T. (2000) "Interagency collaboration and welfare reform" Welfare Information Network Issue Notes, 4(1).

60 Water Resources Commission Organizies Training Workshops Throughout The Country, $16^{\text {th }}$ May, 2015. Available at http://www.wrc-gh.org/news/speech-delivered-by-the-chairman-of-water-reso urces-commission-agyewodin-adu-gyamfi-ampem-on-the-launch-of-ripiran-buffer-zone-policy/. Last assessed on 8/11/2016. 
assessment containing such information within a stipulated period. When the EPA requires the holder of mineral rights to submit an environmental impact assessment, EPA shall inform the Minerals Commission and any government agency which has the responsibility to issue license, permit, approval or consent for mineral operations to withhold its license, permit, approval or consent until EPA informs the government agency that the mandates under the environmental impact assessment have been complied with ${ }^{61}$.

In fact, the Environmental Protection Agency can issue an enforcement notice against a mineral rights holder at any time when it appears to EPA that the undertaking of the mineral rights holder poses a serious threat to the environment or public health ${ }^{62}$. In the enforcement notice, EPA may require the mineral rights holder to take such steps as the EPA thinks necessary to remedy the situation. The enforcement notice may also direct the mineral rights holder to cease operations immediately where the Agency thinks fit until the offending act has been remedied ${ }^{63}$. A mineral rights holder who acts in contravention of an enforcement notice issued by the EPA commits an offence and shall be liable on summary conviction to a fine and in default to a term of imprisonment ${ }^{64}$.

Furthermore the water rights granted under the Water Resources Commission Act can be suspended or canceled for improper use. Under Regulations 24 of the Water Use Regulations, a water "permit holder who interferes with or who permits a person to interfere with a controlling or measuring device so that the quantity of water abstracted, diverted or stored is not in accordance with the terms of the holder's permit or is not in accordance with the terms of an order of the Commission commits an offence and is liable on summary conviction to a fine not exceeding two hundred and fifty penalty units or to a term of imprisonment not exceeding twelve months or to both." 65

\section{H. Conclusion}

The Integrative approach to water use management seems apt. However, the approach needs strengthening to make it effective to manage water use in mining operations. Thus the working group concept where the Environmental Protection Agency, Water Resources Commission and the Minerals Commission among other agencies sit to deal with permitting issues of common interest is therefore very useful to holistically deal with problems and concerns that may emanate during the process.

One of the Minerals Commission's primary functions is facilitating the issuing of mining permits. Based on its advisory role, it also advances government policies on increasing investment in the mining sector for purposes of revenue generation for the government.

61 Environmental Protection Agency Act, 1994 (Act 490) section 12.

62 Ibid section 13.

63 Ibid.

64 Ibid.

65 Water Use Regulations, 2001 (L.I. 1692). 
A working group style approach to permitting therefore will ensure that the Commission will among other things critically consider issues of sustainable water use and general environmental management when deciding on the issuance of permits. In any case, adverse water use practices in mining operations will increase the social cost to mining and thereby reduce the net revenue that will accrue to the State. With this in mind, the working groups may impress on the Minerals Commission to advice the Minister to exercise his/her powers under section 4 of the Minerals and Mining Act to declare fragile ecologies as areas that cannot be the subject matter of a mineral right. However, the integrative working group approach will function optimally if the personnel selected from each agency possess the requisite technical skills to impact the decision of the group. In addition, although the membership of the working group is made up of bureaucrats, there should be an effort to ensure that members are changed in a way that will not affect institutional learning and institutional experience. If a critical mass of the membership of the group are changed en masse either by way of transfers or retirement, the group may experience some level of dysfunction. Although the dysfunction may be temporary, important decisions may be affected during the period of the dysfunction.

In the end, an effective water rights system should involve the local authorities in whose jurisdiction these water resources are. The traditional authorities and their people live in the communities and they can become important allies to assist the proper assignment of water rights to ensure sustainable mining and to avoid conflict among different users. However, it appears that there are still a large number of communities in the rural areas who are unaware of the statutory interventions in the area of water resource ownership and the process of assigning property rights to water ${ }^{66}$. To these communities, the traditional authorities still remain the entities with the power to grant water rights ${ }^{67}$. However the narrow view with which traditional authorities view water use is such that they will often not take decisions in the best interest of the different users who may be beyond the traditional area but rather scattered throughout the country. For such communities, the education of the Water Resources Commission should be intensified to update them on the legislative changes. There should also be increased policing and monitoring to ensure that the permitting processes are followed in accordance with the law.

66 Ainuson, K. (2010) Urban Water Politics and Water Security in Disadvantaged Urban Communities in Ghana. African Studies Quarterly | Volume 11, Issue 4 | Summer 2010.

67 Supra. 